\title{
Mineral profile of some selected citrus fruits collected from different localities of District Sargodha
}

Ayesha Rasool ${ }^{1}$, Mujahid Hussain ${ }^{1 *}$, Iftikhar Ahmad ${ }^{1}$, Abdul Ghani ${ }^{1}$, Muhammad Nadeem ${ }^{2}$, Muhammad Ikram ${ }^{1}$ and Muhammad Imran ${ }^{1}$

1. Department of Botany, University of Sargodha, Sargodha, Punjab-Pakistan

2. Institute of Food Science and Nutrition, University of Sargodha, Sargodha, Punjab-Pakistan

*Corresponding author's email: mujahid.hussain7877@gmail.com

Citation

Ayesha Rasool, Mujahid Hussain, Iftikhar Ahmad, Abdul Ghani, Muhammad Nadeem, Muhammad Ikram and Muhammad Imran. Mineral profile of some selected citrus fruits collected from different localities of District Sargodha. Pure and Applied Biology. Vol. 9, Issue 4, pp2489-.2496. http://dx.doi.org/10.19045/bspab.2020.90265

\begin{tabular}{llll}
\hline \hline Received: 13/04/2020 & Revised: 01/07/2020 & Accepted: 06/07/2020 & Online First: 06/08/2020
\end{tabular}

\section{Abstract}

The present study was conducted to determine the mineral profile of some selected Citrus fruits collected from different localities of district Sargodha i.e. Silanwali, Sargodha, Bhalwal. Plants include Citrus reticulata early mandarin (feutrell's early), Citrus paradisi (Grapefruit), Citrus reticulata mandarin (Kinnow), Citrus jambhiri (Khatti) and Citrus sinensis (Musambi). Results of the mineral analysis showed that the maximum concentration of Fe $(6.52 \pm 0.12 \mathrm{mg} / 100 \mathrm{~g}), \mathrm{Mn}$ $(0.98 \pm 0.08 \mathrm{mg} / 100 \mathrm{~g}), \mathrm{Cr}(0.46 \pm 0.03 \mathrm{mg} / 100 \mathrm{~g})$ and $\mathrm{Zn}(1.88 \pm 0.10 \mathrm{mg} / 100 \mathrm{~g})$ were analyzed in Citrus sinensis collected from Sargodha and Bhalwal respectively while the highest concentration of $\mathrm{PO}_{4}(8.10 \pm 0.09 \mathrm{mg} / 100 \mathrm{~g}), \mathrm{Cu}(33.59 \pm 0.05 \mathrm{mg} / 100 \mathrm{~g})$ and $\mathrm{Ca}(50.71 \pm 0.07 \mathrm{mg} / 100 \mathrm{~g})$ were noted in Citrus jambhiri and Citrus reticulata early mandarin collected from Bhalwal and Silanwali respectively. A highly significant variation in the mineral profile of all selected plants were observed which may be attributed to different environmental factors i.e. soil composition, water, temperature or may be linked to spatial variations.

Keywords: Citrus fruits; District Sargodha; Mineral profile; Pakistan

\section{Introduction}

Citrus is well known as the world's important fruit crop that is produced in a lot of parts of the world with different environmental conditions. Pakistan is one of the major citrus producer countries in the world. Citrus production is assessed to be 105 MMT per annum [1]. Pakistan establishes about 30\% of the area under all citrus orchids represented by 11 genera and 27 species [2]. Pakistan is the twelfth citrus-producing country both in an area under cultivation (199.9 thousand hectares) and fruit production (2.35 MMT) growing at an average annual rate of $3.93 \%$ $[3,4]$.

Citrus is grown in all four provinces of Pakistan but Punjab produces over $98 \%$ with an area of 183.21 thousand hectares under cultivation and 2.31 MMT in fruit production because of its greater population and favorable growing conditions [4]. Major varieties of citrus produced by Punjab includes Mandarins (Kinnow and Feutrell's early), Sweet Oranges (Musambi, Succri, Jaffa, Red Blood, Ruby Red), Lemon (Rough Lemon, Lisbon Lemon, Eureka), Lime 
(Kaghzi lime, Sweet lime), Grapefruit (Mash seedless, Duncan, Foster, Shamber) [5]. A large part of citrus fruits consumed locally, however $10-12 \%$ of total production is exported to other countries of Asia and Europe. About $86 \%$ of citrus is covered by Kinnow followed by Musambi (10\%), Feutrell's early (4\%), Blood Red (1\%) [4].

Different parts of citrus fruits possess various nutritive and therapeutic value. Citrus fruits and juice are excellent sources of healthpromoting substances which are essential for many physiological functions of the body i.e. these are an important source of minerals that are vital to human health and survival. $5 \%$ of body mass is considered as minerals [6], as part of myoglobin, hemoglobin, maintain $\mathrm{pH}$, acting as a catalyst in many biological reactions, important for proper food digestion, metabolism and Utilization of all the nutrients in food [3]. Minerals are also important to our mental health i.e. memory, learning. Helpful in curing headache, weakness, stress, chronic fatigue, osteoporosis [7], arthritis, cancer, premenstrual disorders. These also take part in the formation of bones, teeth, enzymes, hormones, tissues [8], also used in fat and carbohydrate metabolism, ATP formation and cell proliferation [7]. This study is illustrating the mineral profile of some selected citrus fruits collected from different localities of district Sargodha.

\section{Materials and methods}

The study was conducted to analyze the mineral profile of some selected citrus fruits collected from different localities of district Sargodha (Fig. 1) i.e. Silanwali (S1), Sargodha (S2), Bhalwal (S3) while selected citrus fruits include Citrus reticulata early mandarin (feutrell's early) (P1), Citrus paradisi (Grapefruit) (P2), Citrus reticulata mandarin (Kinnow) (P3), Citrus jambhiri (Khatti) (P4), Citrus sinensis (Musambi) (P5).

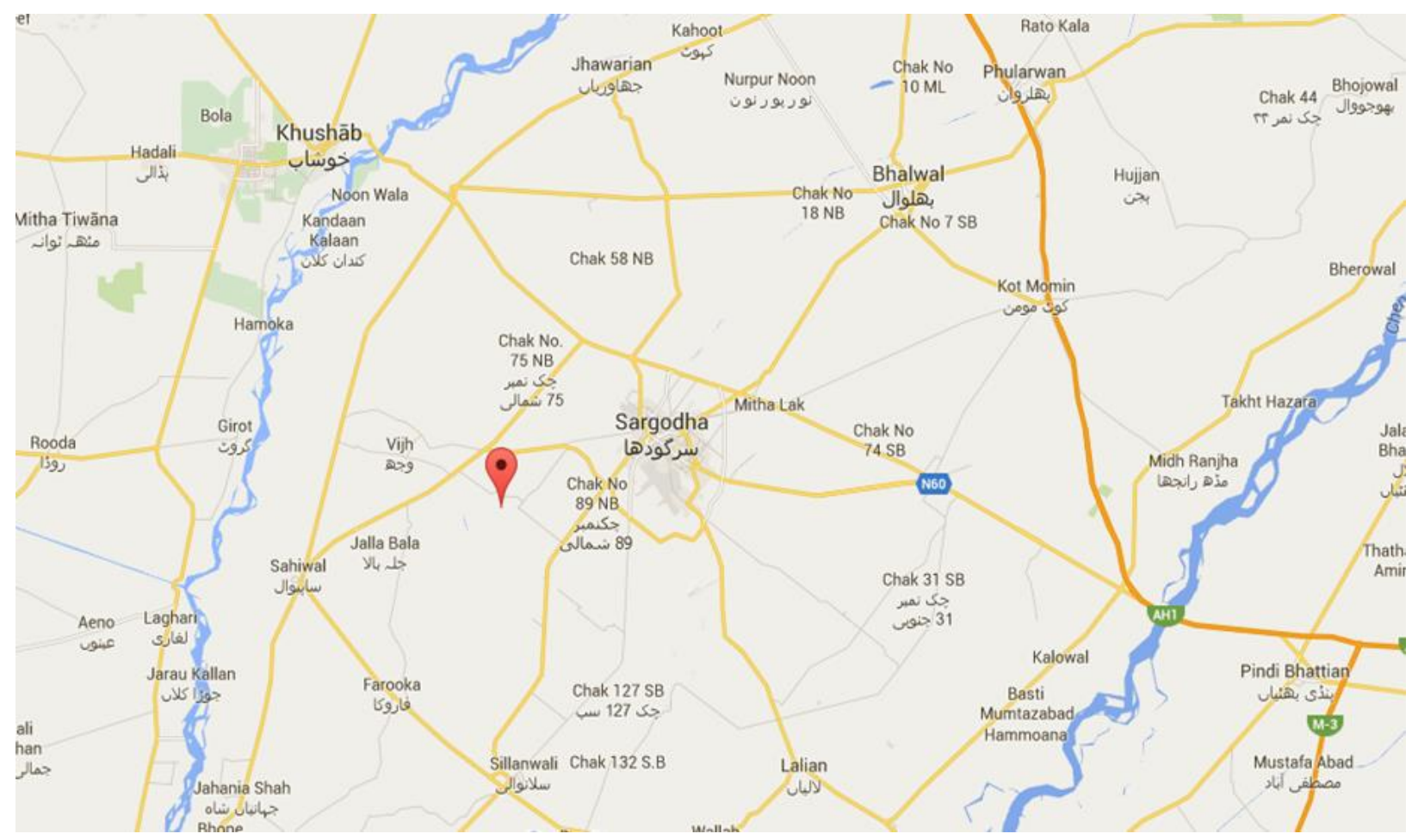

Figure 1. The map of district Sargodha (Google Map data) 


\section{Sample collection}

Fruit samples of all selected plants were collected from all three sites for analysis. Each sample comprised of three replicates. Each sample was randomly handpicked, wrapped in a specific brown envelope, labeled and brought to the Department of Botany, University of Sargodha, Sargodha for further analysis.

\section{Mineral analysis (mg/100g)}

Elemental analysis was carried out according to the method AOAC [9]. Following Metals were studied using standard methods which include phosphate $\left(\mathrm{PO}_{4}\right)$, calcium $(\mathrm{Ca})$, chromium $(\mathrm{Cr})$, copper $(\mathrm{Cu})$, iron $(\mathrm{Fe})$, manganese $(\mathrm{Mn})$, and zinc $(\mathrm{Zn})$.

\section{Digestion of fruit samples}

The oven-dried fruit samples were grinded into a fine powder and then digested by a wet digestion method. $0.5 \mathrm{~g}$ of samples were taken into the digestion flask, $10 \mathrm{ml} \mathrm{HNO}_{3}$ was added in each sample and kept it overnight. Then the process of digestion was carried out on a hot plate by adding $5 \mathrm{ml}$ Perchloric acid in the sample. The process was repeated until the sample solution becomes transparent. Then distilled water was added to make the solution up to $100 \mathrm{ml}$. Then standard solutions were also prepared for each element to be analyzed.

For elemental analysis, the filtered solution samples were loaded to the atomic absorption spectrophotometer (Model: Varian AA-240). The standard curve for each metal was prepared by running the standard solution. The mineral contents of the samples were estimated by standard curve prepared for each metal [9].

\section{Statistical analysis}

Results were statistically analyzed (Table 1) by analysis of variance and LSD using SPSS software [10].

Table 1 Analysis of variance of data regarding mineral profile in some selected citrus fruits collected from different localities of district Sargodha

\begin{tabular}{|c|c|c|c|c|c|c|c|c|}
\hline$\frac{\text { ANOVA }}{\text { SOV }}$ & DF & $\mathbf{C a}$ & $\mathrm{Cr}$ & $\mathbf{C u}$ & $\mathbf{F e}$ & Mn & $\mathrm{PO}_{4}$ & $\mathbf{Z n}$ \\
\hline Sites & 2 & $2497.45 * *$ & $0.10640 * *$ & 958.815** & $15.5546 * *$ & $0.30880^{* *}$ & 25.8776 ** & $0.32074 * *$ \\
\hline Plants & 4 & $37.14 * *$ & $0.00788^{* *}$ & $7.420 * *$ & $0.1564 * *$ & $0.00435^{\mathrm{NS}}$ & $0.0691^{* *}$ & $0.04310^{\mathrm{NS}}$ \\
\hline $\begin{array}{l}\text { Sites * } \\
\text { Plants }\end{array}$ & 8 & $25.37 * *$ & $0.01673 * *$ & $3.706 * *$ & $1.1354 * *$ & $0.06693 * *$ & $0.8642 * *$ & $0.02207^{\mathrm{NS}}$ \\
\hline Error & 30 & 0.19 & 0.00104 & 0.027 & 0.0252 & 0.00968 & 0.0074 & 0.01948 \\
\hline Total & 44 & & & & & & & \\
\hline
\end{tabular}

\section{Results and discussion}

Phosphorous is an essential constituent of bones, DNA, RNA, ATP. It makes up 0.5 to $1.1 \%$ of the human body, involved in many functions i.e. filtering waste, repairing tissues and cells. However, too much accumulation of phosphorus in the body leads to several health hazards which includes kidney disorders, heart diseases, joint pain and fatigue [3]. Results of the study showed that the maximum concentration of $\mathrm{PO}_{4}$ was observed in P4 collected from S3 while the minimum was observed in P5 collected from
S2 with the mean value of $5.88 \pm 1.58$ $\mathrm{mg} / 100 \mathrm{~g}$ as shown in (Table 2). Results regarding $\mathrm{PO}_{4}$ in different varieties of citrus fruits are in collaboration with the findings of [11]. They showed that level of phosphorous ranged from 1.1 to $18.6 \mathrm{mg} / 100 \mathrm{~g}$ in different varieties of citrus while findings of [12] showed that orange $(12 \mathrm{mg} / 100 \mathrm{~g})$ and grapefruit $(8 \mathrm{mg} / 100 \mathrm{~g})$ are also a good source of $\mathrm{PO}_{4}$. Normal intake of phosphorus for adults and children should not be exceeded from $580 \mathrm{mg} /$ day and 460 to $1250 \mathrm{mg} /$ day respectively as suggested by [13]. 
Table 2. Mean values of data regarding $\mathrm{PO}_{4}$ in some selected citrus fruits collected from different localities of district Sargodha

\begin{tabular}{|c|c|c|c|c|c|c|}
\hline \multirow{2}{*}{ Sites } & \multicolumn{5}{|c|}{ Plants } & \multirow{2}{*}{ Mean } \\
\cline { 2 - 6 } & P1 & P2 & P3 & P4 & P5 & \\
\hline S1 & $5.11 \pm 0.25 \mathrm{~g}$ & $7.94 \pm 0.03 \mathrm{~b}$ & $4.77 \pm 0.05 \mathrm{~h}$ & $7.79 \pm 0.08 \mathrm{c}$ & $4.11 \pm 0.09 \mathrm{ij}$ & $5.94 \pm 1.65 \mathrm{~A}$ \\
\hline S2 & $5.85 \pm 0.11 \mathrm{f}$ & $7.39 \pm 0.06 \mathrm{~d}$ & $4.15 \pm 0.09 \mathrm{i}$ & $8.07 \pm 0.04 \mathrm{ab}$ & $3.97 \pm 0.10 \mathrm{j}$ & $5.88 \pm 1.71 \mathrm{~A}$ \\
\hline S3 & $4.85 \pm 0.07 \mathrm{~h}$ & $6.78 \pm 0.11 \mathrm{e}$ & $4.17 \pm 0.09 \mathrm{i}$ & $8.10 \pm 0.09 \mathrm{a}$ & $5.14 \pm 0.13 \mathrm{~g}$ & $5.81 \pm 1.48 \mathrm{~B}$ \\
\hline Mean & $5.27 \pm 0.45 \mathrm{C}$ & $7.37 \pm 0.50 \mathrm{~B}$ & $4.36 \pm 0.31 \mathrm{D}$ & $7.98 \pm 0.16 \mathrm{~A}$ & $4.40 \pm 0.56 \mathrm{D}$ & \\
\hline
\end{tabular}

Calcium is a mineral that makes up approximately 2 percent of the human body. It is vital for life as a major part of our bones, teeth, nerve cells and body tissues [14]. It enables our heart to beat, Nerves to conduct signals, muscles to contract and blood to clot. Also involves in the secretion of certain enzymes. Its absorption is better in young than an old person with vitamin D [15]. Daily intake of calcium reduces blood pressure and cholesterol level especially LDL in blood and incidence of colon cancer [16] while results showed that the highest concentration of $\mathrm{Ca}$ was noted in P5 collected from S2 while the lowest was observed in P4 collected from S3 with the mean value of $28.66 \pm 15.27 \mathrm{mg} / 100 \mathrm{~g}$ (Table 3). Results regarding $\mathrm{Ca}$ in different varieties of citrus fruits are in collaboration with the findings of [17]. They showed that level of $\mathrm{Ca}$ in selected fruits was ranged from $3.1 \pm 0.08$ to $30.0 \pm 3.8 \mathrm{mg} / 100 \mathrm{~g}$ while grapefruit, orange, pomelo contains $20.0 \pm 5.4, \quad 25.5 \pm 1.9, \quad 10.0 \pm 0.8 \quad \mathrm{mg} / 100 \mathrm{~g}$ respectively. RDA for calcium for an adult is $800 \mathrm{mg} /$ day, for teenagers 1200 to $1500 \mathrm{mg} /$ day [18].

Table 3. Mean values of data regarding $\mathrm{Ca}$ in some selected citrus fruits collected from different localities of district Sargodha

\begin{tabular}{|c|c|c|c|c|c|c|}
\hline \multirow{2}{*}{ Sites } & \multicolumn{5}{|c|}{ Plants } & \multirow{2}{*}{ Mean } \\
\cline { 2 - 7 } & P1 & P2 & P3 & P4 & P5 & \\
\hline S1 & $45.99 \pm 0.62 \mathrm{~b}$ & $17.26 \pm 0.09 \mathrm{i}$ & $27.76 \pm 0.05 \mathrm{f}$ & $9.35 \pm 0.12 \mathrm{l}$ & $50.71 \pm 0.07 \mathrm{a}$ & $30.21 \pm 16.54 \mathrm{~A}$ \\
\hline S2 & $44.70 \pm 0.05 \mathrm{c}$ & $13.36 \pm 0.04 \mathrm{j}$ & $24.47 \pm 0.13 \mathrm{~g}$ & $10.50 \pm 0.16 \mathrm{k}$ & $50.43 \pm 0.30 \mathrm{a}$ & $28.69 \pm 16.77 \mathrm{~B}$ \\
\hline S3 & $38.97 \pm 0.86 \mathrm{e}$ & $19.66 \pm 0.20 \mathrm{~h}$ & $25.00 \pm 1.10 \mathrm{~g}$ & $8.49 \pm 0.32 \mathrm{~m}$ & $43.23 \pm 0.30 \mathrm{~d}$ & $27.07 \pm 13.16 \mathrm{C}$ \\
\hline Mean & $43.22 \pm 3.28 \mathrm{~B}$ & $16.76 \pm 2.75 \mathrm{D}$ & $25.74 \pm 1.62 \mathrm{C}$ & $9.45 \pm 0.89 \mathrm{E}$ & $48.12 \pm 3.60 \mathrm{~A}$ & \\
\hline
\end{tabular}

Chromium (Trivalent) is an essential trace element. A very small amount of chromium is necessary for the maintenance of human health. It is important for fat and carbohydrate metabolism, reduce the risk of diabetes, polycystic ovary syndrome, Turner's syndrome, dysthymia. Also lowering cholesterol level in blood [19] while results showed that the maximum concentration of $\mathrm{Cr}$ was noted in $\mathrm{P} 5$ collected from S2 and the minimum was observed in $\mathrm{P} 4$ collected from $\mathrm{S} 1$ with the mean value of
$0.19 \pm 0.11 \mathrm{mg} / 100 \mathrm{~g}$ (Table 4). Results regarding $\mathrm{Cr}$ in citrus showed similar findings with [3]. They showed that level of $\mathrm{Cr}$ in selected citrus fruit varied from 0.15 to $0.063 \mathrm{mg} / \mathrm{Kg}$ while findings of [20] showed that orange fruits contains 46.2 to 84.7 $\mathrm{mg} / \mathrm{Kg}$. A normal dose of chromium for women is suggested as $14-25 \mu \mathrm{g} /$ day while for men, it is suggested as 14-35 $\mu \mathrm{g} /$ day. Children with age between 1-13 years also require chromium ranged between 0.2 to 25 $\mu \mathrm{g} /$ day [21]. 
Table 4. Mean values of data regarding $\mathrm{Cr}$ in some selected citrus fruits collected from different localities of district Sargodha

\begin{tabular}{|c|c|c|c|c|c|c|}
\hline \multirow{2}{*}{ Sites } & \multicolumn{5}{|c|}{ Plants } & \multirow{2}{*}{ Mean } \\
\cline { 2 - 6 } & P1 & P2 & P3 & P4 & P5 & \\
\hline S1 & $0.12 \pm 0.01 \mathrm{fgh}$ & $0.12 \pm 0.04 \mathrm{fgh}$ & $0.15 \pm 0.03 \mathrm{ef}$ & $0.06 \pm 0.02 \mathrm{i}$ & $0.36 \pm 0.04 \mathrm{~b}$ & $0.16 \pm 0.11 \mathrm{~B}$ \\
\hline S2 & $0.19 \pm 0.03 \mathrm{cde}$ & $0.08 \pm 0.01 \mathrm{ghi}$ & $0.22 \pm 0.03 \mathrm{~cd}$ & $0.07 \pm 0.04 \mathrm{hi}$ & $0.46 \pm 0.03 \mathrm{a}$ & $0.20 \pm 0.14 \mathrm{~A}$ \\
\hline S3 & $0.17 \pm 0.02 \mathrm{def}$ & $0.13 \pm 0.02 \mathrm{fg}$ & $0.34 \pm 0.02 \mathrm{~b}$ & $0.14 \pm 0.03 \mathrm{ef}$ & $0.24 \pm 0.04 \mathrm{c}$ & $0.20 \pm 0.08 \mathrm{~A}$ \\
\hline Mean & $0.16 \pm 0.03 \mathrm{C}$ & $0.11 \pm 0.03 \mathrm{D}$ & $0.24 \pm 0.08 \mathrm{~B}$ & $0.09 \pm 0.04 \mathrm{D}$ & $0.36 \pm 0.04 \mathrm{~A}$ & \\
\hline
\end{tabular}

Copper is also an essential trace element that is required for the synthesis of hemoglobin. Important for respiration, oxidative defense system. Keeps bones, CNS, immune system healthy. Maintains body pigmentation, prevents anemia [3] while results showed that the maximum concentration of $\mathrm{Cu}$ was noted in $\mathrm{P} 4$ collected from $\mathrm{S} 3$ and the minimum was observed in $\mathrm{P} 1$ collected from $\mathrm{S} 2$ with the mean value of $17.43 \pm 9.39 \mathrm{mg} / 100 \mathrm{~g}$ (Table 5). Results regarding $\mathrm{Cu}$ in citrus varied with the findings of Ghani et al. [3].
They showed that level of $\mathrm{Cu}$ in selected citrus fruit ranged from 0.15 to $0.063 \mathrm{mg} / \mathrm{Kg}$ while findings of [22] indicate that the concentration of copper is $5.90 \pm 0.075$ $\mathrm{mg} / \mathrm{Kg}$ in citrus fruit. Another has been noted in watermelon, orange and banana 1.22-2.13, $1.27-2.13$ and $2.51-0.95 \mathrm{mg} / \mathrm{Kg}$ respectively while adequate intake for copper is suggested as ranging from 200 to $220 \mu \mathrm{g} /$ day. For adults it is suggested as 340 to $1,300 \mu \mathrm{g} /$ day [23].

Table 5. Mean values of data regarding $\mathrm{Cu}$ in some selected citrus fruits collected from different localities of district Sargodha

\begin{tabular}{|c|c|c|c|c|c|c|}
\hline \multirow{2}{*}{ Sites } & \multicolumn{5}{|c|}{ Plants } & \multirow{2}{*}{ Mean } \\
\cline { 2 - 6 } & P1 & P2 & P3 & P4 & P5 & \\
\hline S1 & $7.70 \pm 0.09 \mathrm{k}$ & $24.14 \pm 0.07 \mathrm{~d}$ & $16.92 \pm 0.07 \mathrm{f}$ & $32.30 \pm 0.10 \mathrm{~b}$ & $8.19 \pm 0.04 \mathrm{k}$ & $17.85 \pm 9.77 \mathrm{~A}$ \\
\hline S2 & $6.59 \pm 0.29 \mathrm{n}$ & $22.73 \pm 0.17 \mathrm{e}$ & $14.51 \pm 0.15 \mathrm{~g}$ & $29.48 \pm 0.25 \mathrm{c}$ & $9.79 \pm 0.16 \mathrm{i}$ & $16.62 \pm 8.71 \mathrm{~B}$ \\
\hline S3 & $6.87 \pm 0.09 \mathrm{~m}$ & $23.88 \pm 0.10 \mathrm{~d}$ & $15.89 \pm 0.23 \mathrm{~g}$ & $33.59 \pm 0.05 \mathrm{a}$ & $8.91 \pm 0.24 \mathrm{j}$ & $17.83 \pm 10.23 \mathrm{~A}$ \\
\hline Mean & $7.05 \pm 0.52 \mathrm{E}$ & $23.58 \pm 0.65 \mathrm{~B}$ & $15.77 \pm 1.05 \mathrm{C}$ & $31.79 \pm 1.82 \mathrm{~A}$ & $8.97 \pm 0.70 \mathrm{D}$ & \\
\hline
\end{tabular}

Iron is an essential mineral that performs many functions in the human body. It involved in the synthesis of hemoglobin, myoglobin, many enzymes and the generation of ATP. About 6 percent used in the formation of collagen and some neurotransmitters. It also plays a vital role in immune cells maturity and in the maintenance of normal cognitive functions i.e. alertness, intelligence, learning [24] while results showed that the highest concentration of Fe was noted in P5 collected from S2 and the lowest was observed in $\mathrm{P} 4$ collected from S2 with the mean value of $3.34 \pm 1.28$ $\mathrm{mg} / 100 \mathrm{~g}$ (Table 6). Results regarding Fe in different varieties of citrus fruits are in collaboration with the findings of [17]. They showed that level of Fe in selected fruits was ranged from $0.11 \pm 0.02$ to $0.60 \pm 0.04$ $\mathrm{mg} / 100 \mathrm{~g}$ while grapefruit, orange, pomeloe contains $\quad 0.50 \pm 0.02, \quad 0.38 \pm 0.02, \quad 0.4 \pm 0.03$ $\mathrm{mg} / 100 \mathrm{~g}$ respectively. RDA for iron for an adult is $20 \mathrm{mg} /$ day but for pregnant women, it needs $50 \mathrm{mg} /$ day as reported by [24]. 
Table 6. Mean values of data regarding $\mathrm{Fe}$ in some selected citrus fruits collected from different localities of district Sargodha

\begin{tabular}{|c|c|c|c|c|c|c|}
\hline \multirow{2}{*}{ Sites } & \multicolumn{5}{|c|}{ Plants } & \multirow{2}{*}{ Mean } \\
\cline { 2 - 7 } & P1 & P2 & P3 & P4 & P5 & \\
\hline S1 & $2.90 \pm 0.08 \mathrm{fg}$ & $3.39 \pm 0.05 \mathrm{e}$ & $2.88 \pm 0.10 \mathrm{fgh}$ & $2.61 \pm 0.03 \mathrm{hij}$ & $5.23 \pm 0.09 \mathrm{~b}$ & $3.40 \pm 0.98 \mathrm{~A}$ \\
\hline S2 & $2.59 \pm 0.22 \mathrm{ij}$ & $3.72 \pm 0.18 \mathrm{~d}$ & $2.68 \pm 0.16 \mathrm{ghi}$ & $1.54 \pm 0.381$ & $6.52 \pm 0.12 \mathrm{a}$ & $3.41 \pm 1.77 \mathrm{~A}$ \\
\hline S3 & $2.18 \pm 0.07 \mathrm{k}$ & $3.56 \pm 0.12 \mathrm{de}$ & $2.40 \pm 0.16 \mathrm{jk}$ & $3.09 \pm 0.09 \mathrm{f}$ & $4.92 \pm 0.13 \mathrm{c}$ & $3.23 \pm 1.28 \mathrm{~B}$ \\
\hline Mean & $2.55 \pm 0.33 \mathrm{CD}$ & $3.55 \pm 0.18 \mathrm{~B}$ & $2.65 \pm 0.24 \mathrm{C}$ & $2.41 \pm 0.71 \mathrm{D}$ & $5.56 \pm 0.74 \mathrm{~A}$ & \\
\hline
\end{tabular}

Manganese is also an important mineral in the human body which plays a vital role in the synthesis of blood clotting factors, sex hormones, enzymes, connective tissues [25]. It also involved in the regulation of blood sugar level, delays the process of aging, and reduces the risk of cancer and heart diseases [3]. Results showed that the level of Mn in selected citrus fruits ranged from 1.09 to 0.37 $\mathrm{mg} / 100 \mathrm{~g}$ while the highest concentration of Mn was noted in P5 collected from S2 and the lowest was observed in $\mathrm{P} 3$ collected from $\mathrm{S} 1$ with the mean value of $0.70 \pm 0.21 \mathrm{mg} / 100 \mathrm{~g}$ (Table 7). Results regarding Mn in different varieties of citrus fruits are in collaboration with the findings of [3]. They showed that level of $\mathrm{Mn}$ in selected citrus fruit was ranged from 0.153 to $0.226 \mathrm{mg} / \mathrm{Kg}$. Adequate intake of manganese for infants ranged from 1.20 to $1.6 \mathrm{mg} /$ day but for children age 9 to 14 , it can be tolerated up to $2.20 \mathrm{mg} / \mathrm{day}$ [21].

Table 7. Mean values of data regarding Mn in some selected citrus fruits collected from different localities of district Sargodha

\begin{tabular}{|c|c|c|c|c|c|c|}
\hline \multirow{2}{*}{ Sites } & \multicolumn{5}{|c|}{ Plants } & \multirow{2}{*}{ Mean } \\
\cline { 2 - 6 } & P1 & P2 & P3 & P4 & P5 & \\
\hline S1 & $0.74 \pm 0.06 \mathrm{~cd}$ & $0.62 \pm 0.06 \mathrm{de}$ & $0.37 \pm 0.06 \mathrm{f}$ & $0.78 \pm 0.08 \mathrm{~cd}$ & $0.96 \pm 0.06 \mathrm{ab}$ & $0.69 \pm 0.20 \mathrm{~A}$ \\
\hline S2 & $0.67 \pm 0.03 \mathrm{cde}$ & $0.52 \pm 0.05 \mathrm{ef}$ & $0.40 \pm 0.04 \mathrm{f}$ & $0.75 \pm 0.04 \mathrm{~cd}$ & $1.09 \pm 0.06 \mathrm{a}$ & $0.68 \pm 0.24 \mathrm{~A}$ \\
\hline S3 & $0.67 \pm 0.08 \mathrm{cde}$ & $0.62 \pm 0.15 \mathrm{de}$ & $0.81 \pm 0.05 \mathrm{bc}$ & $0.51 \pm 0.26 \mathrm{ef}$ & $0.98 \pm 0.08 \mathrm{a}$ & $0.72 \pm 0.20 \mathrm{~A}$ \\
\hline Mean & $0.69 \pm 0.06 \mathrm{~B}$ & $0.59 \pm 0.10 \mathrm{CD}$ & $0.53 \pm 0.21 \mathrm{D}$ & $0.68 \pm 0.18 \mathrm{BC}$ & $1.01 \pm 0.08 \mathrm{~A}$ & \\
\hline
\end{tabular}

Zinc is also a very important metal that improves the body defense system. Plays a vital role in cell growth and division, carbohydrate metabolism, wound healing. It is good for the sexual system, memory and learning, zinc pills are helpful in the treatment of acne, osteoporosis, pneumonia, diarrhea, and the common cold. It delays the process of aging $[19,21]$ while results showed that maximum concentration of $\mathrm{Zn}$ was noted in P5 collected from S3 and the minimum was observed in P1 collected from S3 with the mean value of $1.67 \pm 0.22$ $\mathrm{mg} / 100 \mathrm{~g}$ (Table 8). Results regarding $\mathrm{Zn}$ in different varieties of citrus fruits are in collaboration with the findings of [17]. They showed that level of $\mathrm{Zn}$ in selected fruits was ranged from $0.12 \pm 0.03$ to $0.48 \pm 0.08$ $\mathrm{mg} / 100 \mathrm{~g}$ while grapefruit, orange, pomeloe contains $0.14 \pm 0.06,0.48 \pm 0.08,0.15 \pm 0.04$ $\mathrm{mg} / 100 \mathrm{~g}$ respectively. RDA for zinc is 8 $\mathrm{mg}$ /day for women while during lactation and pregnancy, women may need extra and 11 $\mathrm{mg} /$ day for men while for children with age 6 months to 13 years is suggested as 2 to 8 $\mathrm{mg} /$ day while for above 13 years is suggested as to $13 \mathrm{mg} /$ day [21]. 
Table 8. Mean values of data regarding $\mathrm{Zn}$ in some selected citrus fruits collected from different localities of district Sargodha

\begin{tabular}{|c|c|c|c|c|c|c|}
\hline \multirow{2}{*}{ Sites } & \multicolumn{5}{|c|}{ Plants } & \multirow{2}{*}{ Mean } \\
\cline { 2 - 7 } & P1 & P2 & P3 & P4 & P5 & \\
\hline S1 & $1.54 \pm 0.05 \mathrm{cde}$ & $1.84 \pm 0.04 \mathrm{ab}$ & $1.76 \pm 0.08 \mathrm{abc}$ & $1.61 \pm 0.06 \mathrm{bcde}$ & $1.86 \pm 0.07 \mathrm{a}$ & $1.72 \pm 0.14 \mathrm{~A}$ \\
\hline S2 & $1.38 \pm 0.04 \mathrm{ef}$ & $1.87 \pm 0.12 \mathrm{a}$ & $1.80 \pm 0.05 \mathrm{ab}$ & $1.55 \pm 0.28 \mathrm{cde}$ & $1.69 \pm 0.13 \mathrm{abcd}$ & $1.66 \pm 0.22 \mathrm{AB}$ \\
\hline S3 & $1.23 \pm 0.11 \mathrm{f}$ & $1.73 \pm 0.16 \mathrm{abcd}$ & $1.72 \pm 0.17 \mathrm{abcd}$ & $1.51 \pm 0.26 \mathrm{de}$ & $1.88 \pm 0.10 \mathrm{a}$ & $1.61 \pm 0.27 \mathrm{~B}$ \\
\hline Mean & $1.38 \pm 0.14 \mathrm{C}$ & $1.81 \pm 0.12 \mathrm{~A}$ & $1.78 \pm 0.10 \mathrm{~A}$ & $1.56 \pm 0.20 \mathrm{~B}$ & $1.81 \pm 0.12 \mathrm{~A}$ & \\
\hline
\end{tabular}

\section{Conclusion}

All observed plants have a good source of minerals but there is fluctuation is present in all selected citrus fruits plants, even in the same plant fruits collected from the same as well as from different sites which may be attributed to different agro-climatic conditions or time of fruit harvest. However, the highest concentration of $\mathrm{Fe}, \mathrm{Mn}, \mathrm{Cr}$ and $\mathrm{Zn}$ were analyzed in Citrus sinensis (Musambi) collected from Sargodha and Bhalwal respectively while the maximum concentration of $\mathrm{PO}_{4}, \mathrm{Cu}$ and $\mathrm{Ca}$ were noted in Citrus jambhiri (Khatti) and Citrus reticulata early mandarin (feutrell's early) collected from Bhalwal and Silanwali respectively. Studies also conclude that we have to focus on natural food supplements i.e. if a person is suffering from minerals deficiency than he/she would have to focus on taking more fruits in its diet instead of taking food supplements in the form of capsules, tablets, syrups. i.e. Fe deficiency can also be fulfilled by the intake of iron-rich fruits in its diet instead of taking iron supplements.

Authors' contributions

Conceived and designed the experiments: I Ahmad \& A Ghani, Performed the experiments: A Rasool, Analysed the data: M Nadeem \& M Hussain, Contributed materials/ analysis/ tools: M Ikram \& M Imran, Wrote the paper: M Hussain.

\section{References}

1. Hussain M (2016). Spatial variation in Citrus sinensis L. of district Sargodha. Scholars press
2. Khan SA \& Perveen A (2014). In vitro pollen germination of five citrus species. Pak J Bot 46: 951-956.

3. Ghani A, Hussain M, Ikram M, Nadeem M, Imran M, Majid A, Ahmad I \& Imtiaz A (2017). Comparative analysis of elemental profile of Citrus sinensis collected from five different tehsils of district Sargodha. Pak J Sci 69(4): 343350 .

4. Memon NA (2017). Citrus fruit (Kinnow): Punjab produced $98 \%$ of production. Pak J Food 1(1): 29-31.

5. Siddique MI \& Garnevska E (2016). Citrus value chain (s): A Survey of Pakistan citrus Industry. Agriculture chain value, Pakistan. pp. 37-56.

6. Alexander RT, Hoenderop JG \& Bindels RJ (2008). Molecular determinants of magnesium homeostasis insight from human disease. J Amer Socie Neph 19: 1451-1480.

7. Seifter JL (2016). Potassium disorders. In: Goldman L, Schafer AI, eds. Goldman's Cecil Medicine. 25th ed. Philadelphia, PA: Elsevier Saunders. 117 p.

8. Mason JB (2016). Vitamins, trace minerals, and other micronutrients. In: Goldman L, Schafer AI, eds. GoldmanCecil Medicine. 25th ed. Philadelphia, PA: Elsevier Saunders. 218 p.

9. AOAC (1998). Official Methods of Analysis, $16^{\text {th }}$ Edition, $4^{\text {th }}$ Revision. Association of Official Analytical Chemists, New York

10. Steel RGD, Torrie JH \& Dickey DA (1997). Principle and procedures of 
statistics. A Biometrical Approach. $3^{\text {rd }}$ Ed., McGraw Hill Book Co. Inc. New York, USA.

11. Razi MFD, Khan IA \& Jaskani MJ (2011). Citrus plant nutritional profile in relation to Huanglongbing prevalence in Pakistan. Pak J Agri Sci 48: 299-304.

12. Orwa CA, Mutua R, Kindt R, Jamnadass A \& Simons A (2009). Agroforestree database: a tree species reference and selection guide version 4.0. World Agroforestry Centre ICRAF, Nairobi, KE. 790 p.

13. NASEM (1997). Dietary intakes for calcium, phosphorus, magnesium, vitamin $\mathrm{D}$ and fluoride. Washington (DC): National Academy Press, US.

14. Jackson RD, LaCroix AZ \& Gass M (2006). Calcium plus vitamin D supplementation and the risk of fractures. The New Eng J of Medi 354:669-83.

15. Dawson HB, Harris SS, Krall EA \& Dallal GE (1997). Effect of calcium and vitamin D supplementation on bone density in men and women 65 years of age or older. The New Eng J of Medi 337: 670-676.

16. Lappe JM, Travers-Gustafson D, Davies KM, Recker RR \& Heaney RP (2007). Vitamin D and calcium supplementation reduces cancer risk: results of a randomized trial. Amer J Clin Nutri 85: 1586-1591.

17. Paul DK \& Shaha RK (2004). Nutrients, vitamins and minerals content in common citrus fruits in the northern region of Bangladesh. Pak J Bio Sci 7(2): 238.

18. Otten JJ, Hellwig JP \& Meyers LD (2006). Dietary Reference Intakes: The Essential Guide to Nutrient
Requirements. National Academies Press, USA.

19. Mason JB (2011). Vitamins, trace minerals, and other micronutrients. In: Goldman L, Ausiello D, eds. Goldman's Cecil Medicine. 24th Edition, Philadelphia, PA: Elsevier Saunders. 225 p.

20. Ihesinachi K \& Eresiya D (2014). Evaluation of heavy metals in orange, pineapple, avocado pear and pawpaw from a farm in Kaani, Bori, Rivers State Nigeria. Inter J Environ Res and Pub Heal 1: 87-94.

21. NASEM (2001) Dietary reference intakes for vitamin A, vitamin $\mathrm{K}$, arsenic, boron, chromium, copper, iodine, potassium, iron, manganese, zinc, molybdenum, nickel, silicon, vanadium and cobalt. Washington (DC): National Academy Press, US.

22. Dhiman A, Nanda A \& Ahmad S (2011). Metal analysis in Citrus sinensis fruit peel and Psidium guajava leaf. Toxicol Inter 18: 163-167.

23. NASEM (2011). Dietary intakes: RDA and $\mathrm{Al}$ for vitamins and elements. Washington (DC): National Academy Press, US.

24. Prashanth L, Kattapagari KK, Chitturi RT, Baddam VRR \& Prasad LK (2015). A review on role of essential trace elements in health and disease. $J$ Dr. NTR Uni Heal Sci 4(2): 75-85.

25. Soetan KO, Olaiya CO \& Oyewole OE (2010). The importance of mineral elements for humans, domestic animals and plants-A review. Afri J Food Sci 4(5): 200-222. 